Article

\title{
Marine Bacterium Vibrio sp. CB1-14 Produces Guanidine Alkaloid 6-epi-Monanchorin, Previously Isolated from Marine Polychaete and Sponges
}

\author{
Tatyana Makarieva *, Larisa Shubina, Valeria Kurilenko, Marina Isaeva, Nadezhda Chernysheva, \\ Roman Popov, Evgeniya Bystritskaya, Pavel Dmitrenok and Valentin Stonik
}

G.B. Elyakov Pacific Institute of Bioorganic Chemistry (PIBOC), Russian Academy of Sciences, Prospect 100 let Vladivostoku, 159, 690022 Vladivostok, Russia; shubina@piboc.dvo.ru (L.S.); valerie@piboc.dvo.ru (V.K.); issaeva@piboc.dvo.ru (M.I.); chernysheva.nadezhda@gmail.com (N.C.); prs_90@mail.ru (R.P.); belyjane@gmail.com (E.B.); paveldmt@piboc.dvo.ru (P.D.); stonik@piboc.dvo.ru (V.S.)

* Correspondence: makarieva@piboc.dvo.ru; Tel.: +7-950-295-66-25

Received: 6 February 2019; Accepted: 2 April 2019; Published: 4 April 2019

\begin{abstract}
Twenty-three bacterial strains were isolated from the secreted mucus trapping net of the marine polychaete Chaetopterus variopedatus (phylum Annelida) and twenty strains were identified using 16S rRNA gene analysis. Strain CB1-14 was recognized as a new species of the genus Vibrio using the eight-gene multilocus sequence analysis (MLSA) and genome sequences of nineteen type Vibrio strains. This Vibrio sp. was cultured, and 6-epi-monanchorin (2), previously isolated from the polychaete and two sponge species, was found in the cells and culture broth. The presence of the 6-epi-monanchorin was confirmed by its isolation followed by ${ }^{1} \mathrm{H}$ NMR and HRESIMS analysis. These results showed the microbial origin of the bicyclic guanidine alkaloid $\mathbf{2}$ in C. variopedatus.
\end{abstract}

Keywords: guanidine alkaloids; 6-epi-monanchorin; HRESI MS; ${ }^{1} \mathrm{H}$ NMR spectra; marine bacteria; Vibrio sp.; polychaete; Chaetopterus variopedatus; $16 \mathrm{~S}$ rRNA gene analysis; phylogenetic reconstruction

\section{Introduction}

Various guanidine-containing natural products, isolated from different marine invertebrates, demonstrate antifungal, antibacterial, antiviral, and antitumor properties [1] and are suitable compounds for drug development due to high levels of their bioactivities and water solubility. Moreover, some natural guanidine-containing compounds, such as streptomycin, have already been introduced in the clinic.

Most of the marine guanidine alkaloids found in marine sponges are polycyclic, and two bicyclic representatives of this group, namely monanchorin (1) and 6-epi-monanchorin (2), are known. These compounds were isolated from representatives of two phylogenetically distant taxa, namely marine sponges Monanchora ungiculata and Halichondria panicea (phylum Porifera) [2,3], and marine polychaete Chaetopterus variopedatus (phylum Annelida) [4]. Previously it has been reported that the compound 1 shows weak cytotoxic activity against IC2 murine mast cells [2], while compounds 1 and 2 (Figure 1) are able to inhibit the migration and colony formation of cisplatin-resistant cancer NCCIT-R cells [4]. 

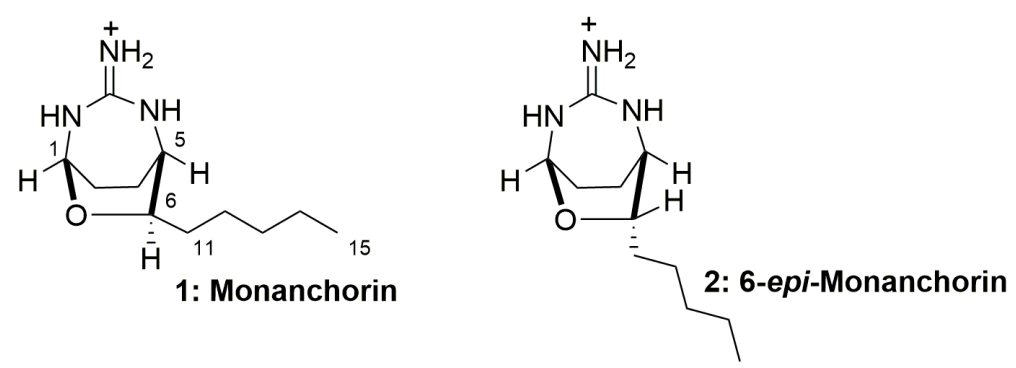

Figure 1. Structures of natural compounds 1 and 2.

The presence of the alkaloids $\mathbf{1}$ and $\mathbf{2}$ in such different taxa could indicate that a common unidentified marine microorganism(s), accumulated in both sponges and the polychaete is a genuine producer of these secondary metabolites of unknown biogenesis. Really, the presence of the same secondary metabolites in distantly related animal taxa sometimes point to potential symbiotic or dietary sources of the corresponding substances. However, experimental evidences of their microbial origin were rarely obtained. Recently, we compared levels of these alkaloid content in different body parts of the polychaete $C$. variopedatus $[5,6]$. Both alkaloids were predominant into the food net parts of the animals and the content of 6-epi-monanchorin (2) was very high (5.0\% of dry weight) [4]. These findings prompted us to undertake the present study. We have tried to identify the biogenetic origin of the above mentioned polychaete metabolites.

\section{Results and Discussion}

\subsection{Isolation of Microorganisms}

The secreted mucous net of the polychaete was pre-rinsed in sterile sea water. Pieces of tissue were aseptically removed and homogenized in sterile sea water. Bacterial strains were isolated by plating samples of tissue homogenates onto medium plates containing the modified MN medium [7]. The plates were incubated aerobically at $20^{\circ} \mathrm{C}$ for 7 days. The bacterial colonies that grew on the Difco ${ }^{\mathrm{TM}}$ Marine Agar 2216 Becton, Dickinson and Company (BD) with that medium were picked up and classified morphologically and biochemically. Twenty-three bacterial strains were isolated in pure cultures and then analyzed by MALDI MS.

2.2. Preliminary Identification of Potential Microorganism-Producers by Monitoring of the Compounds Giving Ion Peaks at $\mathrm{m} / \mathrm{z} 212.17$ by MALDI MS, Characteristic of 1 and 2 MS

A preliminary screening procedure was carried out using Ultrafex III MALDI TOF/TOF mass spectrometer and Biotyper Software (Bruker Daltonics) to select isolates for further analyses. Sample preparation was carried out by "direct transfer" procedure (Ver. 2.0 Biotyper). Spectra were calibrated with external calibration by Eschercihia coli DH5 alpha standard and protein calibration standard I (Bruker Daltonics). The majority of identified bacterial strains were represented by Vibrio spp. and, thus, Vibrio was the dominant group of bacteria cultured from the mucous net of this polychaete. The occurrence of the compounds with a peak at $m / z 212.17$ in MALDI MS, presumably corresponding to 6-epi-monanchorin or monanchorin (2 or $\mathbf{1})$, are shown in the Table 1 . In total there were eleven promising strains found, seven of which were identified as Vibrio spp. and gave this ion peak in MS. It should be noted that the data obtained by this method should be considered as preliminary and did not allow accurate identification, neither microorganisms nor target compounds. 
Table 1. Taxonomic position of microorganism-producers and occurrence of compounds with $\mathrm{m} / \mathrm{z}$ 212.17 ion peak by MALDI MS data.

\begin{tabular}{cccccccc}
\hline No & Strain & Taxon & $m / z \mathbf{2 1 2 . 1 7} *^{*}$ & No & Strain & Taxon & $m / z \mathbf{2 1 2 . 1 7}$ \\
\hline 1 & CB1-3 & nd & nd & 13 & CB2-3 & nd & nd \\
2 & CB1-5 & nd & nd & 14 & CB2-4 & Vibrio sp. & nd \\
3 & CB1-6 & nd & nd & 15 & CB2-5 & Vibrio sp. & nd \\
4 & CB-1-7 & Vibrio sp. & nd & 16 & CB2-6 & Vibrio sp. & + \\
5 & CB1-8 & nd & nd & 17 & CB2-7 & nd & ad \\
6 & CB1-9 & nd & ad & 18 & CB2-8 & Vibrio sp. & ad \\
7 & CB1-10 & Vibrio sp. & ad & 19 & CB2-9 & Vibrio sp. & ad \\
8 & CB1-11 & Vibrio sp. & ad & 20 & CB2-10 & nd & ad \\
9 & CB1-12 & nd & nd & 21 & CB2-11 & Vibrio sp. & + \\
10 & CB1-13 & nd & nd & 22 & CB2-12 & Vibrio sp. & ad \\
11 & CB1-14 & nd & + & 23 & CB2-13 & nd & nd \\
12 & CB2-1 & Vibrio sp. & nd & & & & \\
\hline
\end{tabular}

nd, not detected; ad, ambiguous detected; +, detected.

\subsection{Identification of Compounds $\mathbf{1}$ or $\mathbf{2}$ by HRESIMS}

The authentic identification of compounds $\mathbf{1}$ and $\mathbf{2}$ into the three promising strains such as CB1-14, CB2-11, and CB2-6 (see Table 1) was carried out after isolation of these compounds by HPLC followed by analysis with HRESIMS. The strains were incubated at $200 \mathrm{rpm}$ in $100 \mathrm{~mL}$ of modified MN liquid medium at $28^{\circ} \mathrm{C}$ for 7 days. After incubation, the whole cultures were centrifuged to harvest the bacterial cells. Then cells were suspended in water $(30 \mathrm{ml})$, frozen, and subjected to ultrasonic treatment. The suspension was extracted with EtOAc, and the organic phase was evaporated to dryness. The resulting mixture was dissolved in a small amount of EtOH, and extracts were subjected to HPLC on ODS-A columns. The fractions with retention times of 12 to $17 \mathrm{~min}$ were collected and analyzed by HRESIMS. Compounds showing ion peak with $m / z 212.1757[\mathrm{M}+\mathrm{H}]^{+}$(calcd for $\mathrm{C}_{11} \mathrm{H}_{22} \mathrm{~N}_{3} \mathrm{O}, 212.1757$ ) were isolated from strains CB1-14 and CB2-11. Strain CB1-14 showed a more intense peak at $\mathrm{m} / \mathrm{z}$ 212.1757 compared with that for CB2-11. Their mass spectra were identical to the spectra of standards. As a result, monanchorins were identified in these two strains. However, in order to determine which of two epimeric compounds was biosynthesized by these microorganisms, it was necessary to isolate the alkaloids in amounts sufficient for the obtaining of NMR data.

\subsection{Isolation and Identification of 6-epi-Monanchorin by ${ }^{1} H$ NMR Spectroscopy}

The strain CB1-14 was chosen for preparative isolation of target compounds. After incubation of $12 \mathrm{~L}$ medium at $28^{\circ} \mathrm{C}$ for 7 days, the culture broth of Vibrio sp. strain CB1-14 was separated from cells by centrifugation. The 6-epi-monanchorin (2, Figure 1$)$ was isolated from the EtOAc extracts of both cells and lyophilized culture broth using reverse-phase HPLC. The structure was exactly identified on the basis of ${ }^{1} \mathrm{H}$ NMR and HRESIMS data by comparison with authentic sample [4]. As a result, it was found that the CB1-14 strain biosynthesizes 6-epi-monanchorin (2). Monanchorin itself was not found in this strain in amounts sufficient for NMR spectrum recording.

\section{5. $16 \mathrm{~S}$ rRNA Gene Sequence Analysis of Bacterial Isolates}

Twenty bacterial isolates selected for screening for compounds $\mathbf{1}$ and $\mathbf{2}$ production were identified by $16 \mathrm{~S}$ rRNA gene analysis on the EzBiocloud server [8]. Based on the sequence comparison to reference type strains, the isolates were assigned to the two bacterial phyla (Proteobacteria and Firmicutes). Two isolates (CB1-13 and CB1-18) showed the highest similarity values with Bacillus hwajinpoensis SW-72 ${ }^{\mathrm{T}}(99.21 \%-99.24 \%)$ and Bacillus hemicentroti JSM $076093^{\mathrm{T}}$ (98.27\%). One isolate (CB1-3) shared the highest similarity value with Pseudovibrio japonicus WSF2 ${ }^{\mathrm{T}}(99.2 \%)$, Pseudovibrio ascidiaceicola DSM $16392^{\mathrm{T}}$ (98.99\%), and Pseudovibrio denitrificans DSM $17465^{\mathrm{T}}$ (98.91\%) from Alphaproteobacteria. The others 
were closely related to the species of the genus Vibrio from Gammaproteobacteria. The isolates CB1-14, CB2-10, CB2-8, and CB1-5 showed 98.96\%-99.58\% sequence similarity with Vibrio hangzhouensis CN83T. The other isolates CB2-5, CB1-7, and CB2-12 had 98.79\%-100\% sequence similarity with Vibrio barjaei $3062^{\mathrm{T}}$ and Vibrio thalassae MD16 ${ }^{\mathrm{T}}$. Most of isolates (CB1-1, CB1-10, CB1-11, CB2-4, CB2-9, CB2-11, and CB2-13) shared the highest similarity values with Vibrio mediterranei CIP $103203^{\mathrm{T}}(99.65 \%)$ and Vibrio shilonii $\mathrm{AK}^{\mathrm{T}}$ (99.59\%). Three isolates (CB1-6, CB2-1 and CB2-7) showed similarity values less than $97.5 \%$ with reference type strains of the species of genus Vibrio.

The phylogenetic tree based on the 16S rRNA sequences (1438 bp) clearly showed that Vibrio isolates grouped into four clades (Figure 2), three of which included the single type strains, $V$. barjaei or $V$. hangzhouensis or V. mediterranei. The fourth clade was at the base of the genus Vibrio and did not include any type strains.

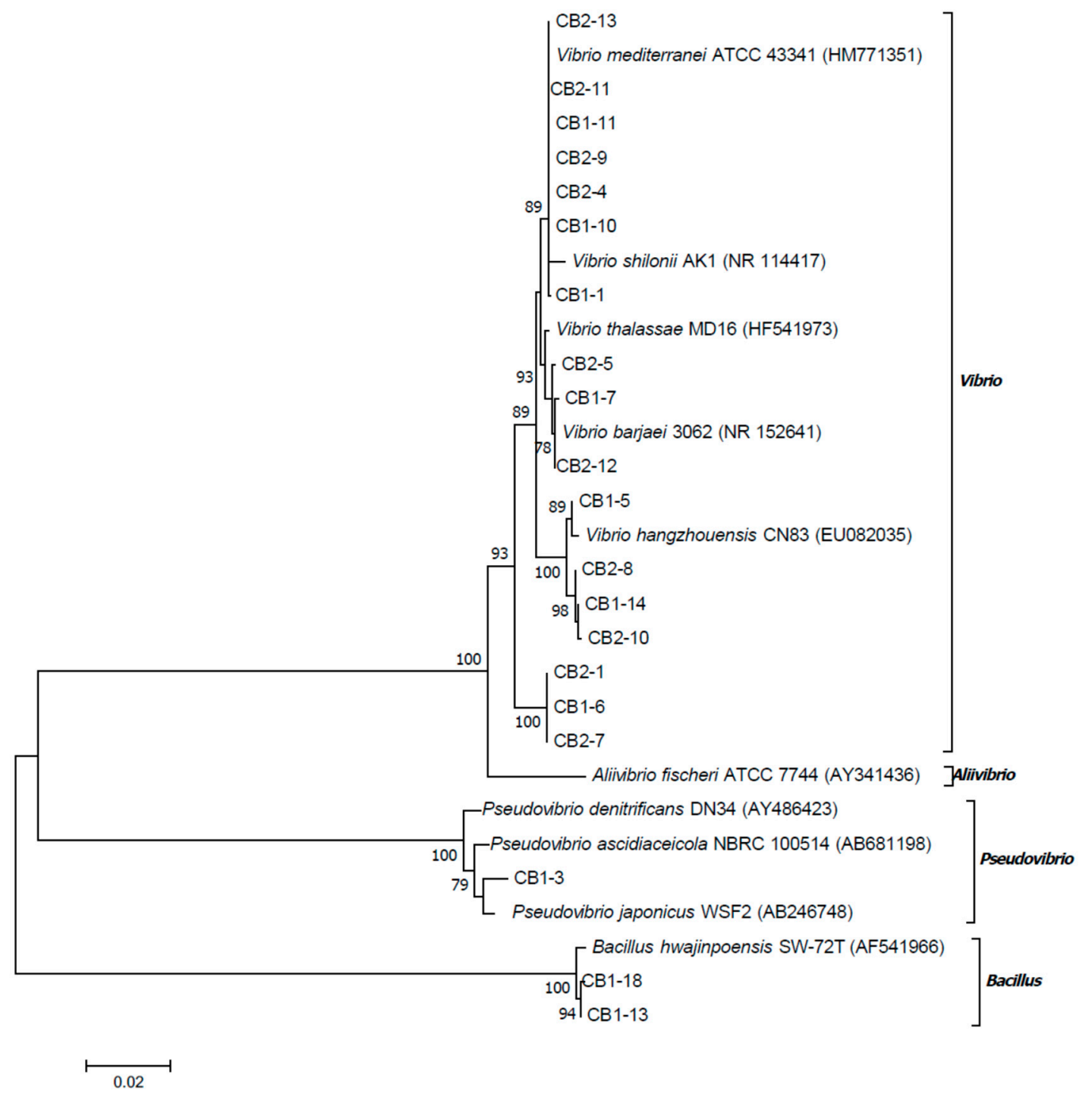

Figure 2. Bacterial phylogenetic tree on the basis of $16 \mathrm{~S}$ rRNA gene sequences of isolates recovered from the mucus net of the $C$. variopedatus and closely related sequences of type strains. The tree topology was obtained using the maximum likelihood method based on the Tamura three-parameter model. Bootstrap values above $75 \%$ calculated from 1000 re-sampling are shown on the node. The scale bar represents the number of substitutions per site.

Guided by the cutoff value at the species level equal to $98.65 \%$ [9] and phylogenetic positions, the isolates CB1-13 and CB1-18 might be identified as B. hwajinpoensis and the isolate CB1-3 as P. 
japonicus. Among Vibrio isolates, the isolates CB2-5, CB1-7, and CB2-12 might be identified as V. barjaei, the isolate CB1-5 as V. hangzhouensis, and the isolates CB1-1, CB1-10, CB1-11, CB2-4, CB2-9, CB2-11, and CB2-13 as V. mediterranei. The clades, containing CB1-14 and CB2-1, might be distinguished as candidates for new species. Thus, one of bacterial strain (CB1-14) presumably producing monanchorins was identified as Vibrio sp., closely related to Vibrio hangzhouensis $\mathrm{CN} 83^{\mathrm{T}}$, but probably distinguished from this species.

Therefore, the phylogenetic analysis revealed bacterial diversity in the mucus net of the $C$. variopedatus. The dominant cultured bacteria were members of the genus Vibrio, belonging, at least, to three different species.

\subsection{Multilocus Sequence Analysis of CB1-14}

The phylogenic analysis based on 16S rRNA gene sequences showed the isolate CB1-14 was closely related to $V$. hangzhouensis $\mathrm{CN} 83^{\mathrm{T}}$, sharing $98.96 \%$ identity with this strain. It means that the calculated identity value is within the boundary range proposed for delineating Vibrio species [10]. Since the 16S rRNA gene sequence did not help in differentiating closely related bacterial species, the eight-gene MLSA was applied as that currently used for delimitating Vibrio species [11,12].

To overcome difficulties in application of universal primers for the MLSA, the draft genome of CB1-14 was obtained and used to retrieve sequences of eight housekeeping genes. Following previously described MLSA scheme [11] and using available genome sequences of nineteen type strains including V. maritimus CAIM $1455^{\mathrm{T}}$, V. variabilis CAIM $1457^{\mathrm{T}}, V$. mediterranei NBRC $15635^{\mathrm{T}}$, and $V$. hangzhouensis CGMCC-1-7062 ${ }^{\mathrm{T}}$, the MLSA study was performed. Based on phylogenies generated by ML (Maximum Likelihood), MP (Maximum Parsimony), and NJ (Neighbor Joining) methods (data are not presented) and split tree decomposition analysis (Figure 3), the MLSA placed the isolate CB1-14 into the Mediterranei clade. Within the clade, the isolate CB1-14 formed a separate branch closely related to $V$. maritimus CAIM $1455^{\mathrm{T}}$ and $V$. variabilis CAIM $1457^{\mathrm{T}}$, with a high bootstrap support.

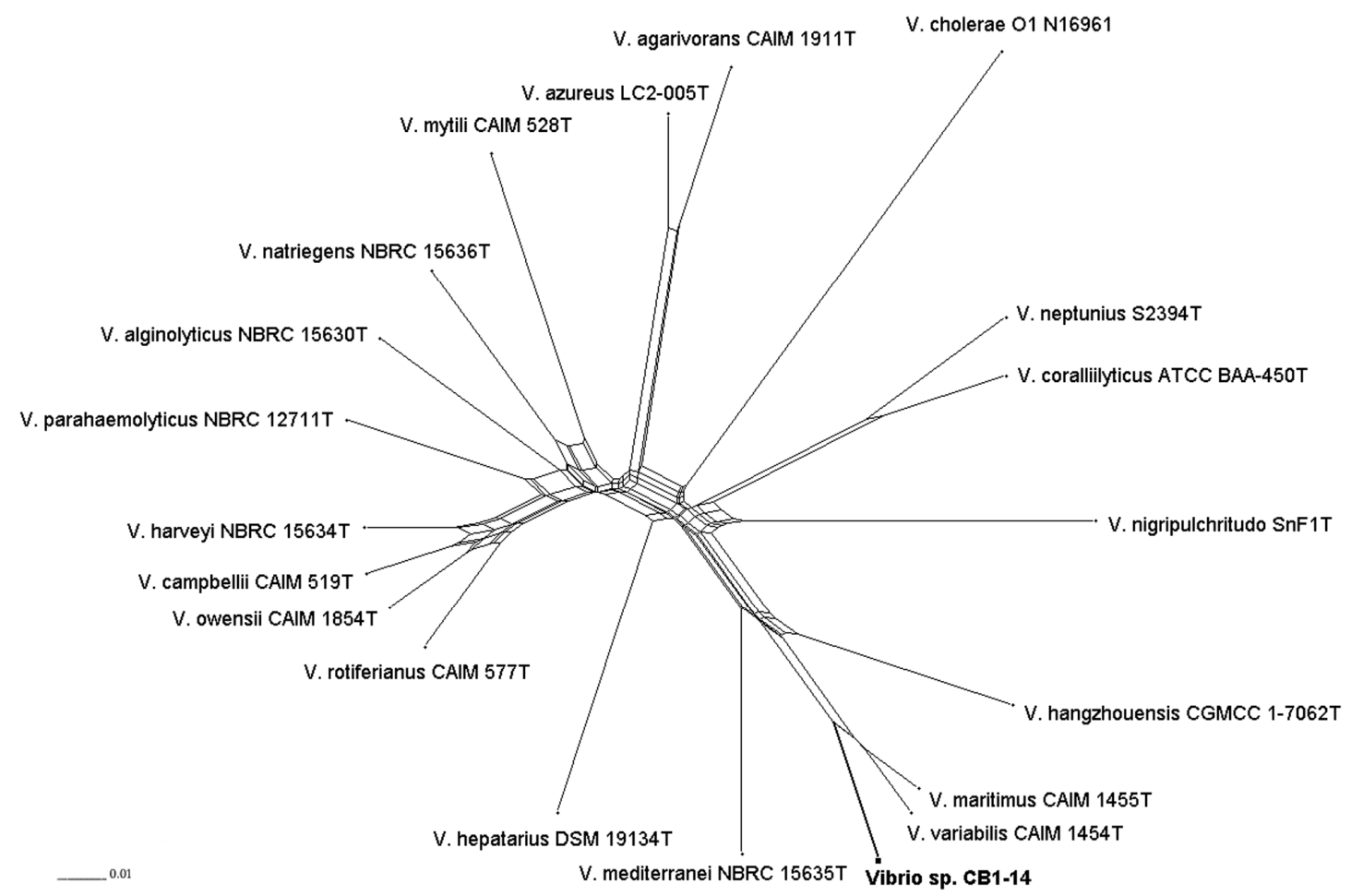

Figure 3. Concatenated split network tree based on eight gene loci. The $f t s Z, g a p A, g y r B$, mreB, pyrH, $r e c A, r p o A$, and top $A$ gene sequences from 20 taxa were concatenated including the isolate CB1-14 (bold font). Phylogenetic tree was generated using the SplitsTree4 program. 
Thus, the phylogenetic reconstruction showed that the isolate CB1-14 should be recognized as a new species in the genus Vibrio. The valid description of this new species in Vibrio genus, isolated from an organ of the polychaete, namely from its mucous net, will be done in a special journal.

Marine invertebrates are the oldest animals on Earth, distributed over all the ocean biomes from polar to tropical waters and from shallow to very deep substrates. In the course of their evolution, marine invertebrates have acquired long-term and stable associations with a wide diversity of bacteria, cyanobacteria, archaea, and other groups of microbes, which make up to $60 \%$ of the biomass of some these animals and are essential to their survival [13]. There are a number of reports that cultures of microorganisms, isolated from marine sponge [14-19] and ascidian tissues [20], produce secondary metabolites previously isolated from these invertebrates, that indicates their microbial origin [13]. However, up to date, only biosurfactants were identified from polychaete-associated microbial isolates [21]. Production of the 6-epi-monanchorin by Vibrio sp. CB1-14 isolate is completely unprecedented. Most of the compounds so far isolated from Vibrio spp. were proved to be non-ribosomal peptides or their hybrids. Only a few guanidine-containing secondary metabolites were isolated from Vibrio, for example siderophore vanchrobactin from Vibrio anguillarum [22] as well as Na channel blocker tetrodotoxin and its derivatives from bacteria V. alginolyticus, V. harveyi, V. fischeri, and Vibrio sp. [23-26].

Our finding that the Vibrio sp. CB1-14 isolate, obtained from polychaete food net and which is able to biosynthesize compound $\mathbf{2}$, shows that this bacterium (and probably some other close related species) has important unrecognized biosynthetic capabilities, and should be considered as a potential microbial source of monanchorins. From the biotechnological viewpoint, the cultivation of bacteria after optimization of 6-epi-monanchorin production could help to solve the recognized supply problem of marine-derived drugs. Identification of this producer also opens prospects of bicyclic guanidine alkaloid biosynthesis.

\section{Materials and Methods}

\subsection{General}

The ${ }^{1} \mathrm{H}-\mathrm{NMR}$ spectra were recorded on a Bruker Avance III-700 spectrometer in $\mathrm{CDCl}_{3}$. Chemical shifts were referenced to the corresponding residual solvent signal $\left(\delta \mathrm{H} \mathrm{7.26/ \delta C} 77.20\right.$ for $\left.\mathrm{CDCl}_{3}\right)$. ESI mass spectra (including HRESIMS) were obtained on a Bruker maXis Impact II LC-MS spectrometer by direct infusion in MeOH. MALDI-TOF mass spectra were obtained on a Bruker Ultraflex III TOF/TOF laser desorption spectrometer coupled with delayed extraction using a Smartbeam MALDI 200 laser with $\alpha$-cyano-hydroxy cinnamic acid as the matrix. HPLC was performed on a Shimadzu instrument with a RID-10A refractive index detector using a YMC-ODS-A $(250 \times 10 \mathrm{~mm})$ column.

\subsection{Animal Material}

Three specimens of the polychaete C. variopedatus were collected from the coastal waters by scuba at a depth of 6-10 m (salinity 33\%, temperature 20) in Troitsa bay, Peter the Great Gulf, Sea of Japan, Russia, in August 2016 and identified by Dr. B. B. Grebnev (GB Elyakov Pacific Institute of Bioorganic Chemistry of Far Eastern Branch of Russian Academy of Sciences, Vladivostok, Russia).

\subsection{Isolation of Microorganisms}

The secreted mucous net of polychaete were pre-rinsed in sterilized sea water. Pieces of tissue (about $1 \mathrm{~g}$ ) were aseptically removed and homogenized in $5 \mathrm{~mL}$ sterilized sea water. Bacterial strains were isolated by plating samples of tissue homogenate $(0.1 \mathrm{~mL})$ onto Petri dishes with the modified $\mathrm{MN}$ medium containing $75 \%$ natural sea water, $25 \%$ distilled water, $0.12 \mathrm{mM} \mathrm{CaCl}_{2}, 0.15 \mathrm{mM} \mathrm{MgSO}_{4}$ $\times 7 \mathrm{H}_{2} \mathrm{O}, 0.09 \mathrm{mM} \mathrm{K}_{2} \mathrm{HPO}_{4} \times 3 \mathrm{H}_{2} \mathrm{O}, 8.8 \mathrm{mM} \mathrm{NaNO}_{3}, 0.19 \mathrm{mM} \mathrm{Na}_{2} \mathrm{CO}_{3}, 0.0013 \mathrm{mM}$ disodium EDTA, $0.014 \mathrm{mM}$ Citric acid $\times \mathrm{H}_{2} \mathrm{O}, 0.015 \mathrm{mM}$ Ferric ammonium citrate, $1 \%$ Bacto agar at $\mathrm{pH}$ 8.5. These dishes were incubated aerobically at $20^{\circ} \mathrm{C}$ for 10 days. The bacterial colonies that grew on the modified MN medium were picked up and then pure bacterial cultures were grown on Difco ${ }^{\mathrm{TM}}$ Marine Agar 2216 
(BD) and classified morphologically and biochemically. Bacterial strains were stored in $30 \%$ glycerol solution at $-80^{\circ} \mathrm{C}$.

\subsection{Identification of Microorganisms by MALDI MS}

Bacterial isolates were stored at $-80^{\circ} \mathrm{C}$ on the Microbank system (VWR, Darmstadt, Germany). Selected colonies were isolated from plates using a sterile pipette tip and applied directly onto a 384-position ground steel target plate (Bruker Daltonics, Bremen, Germany). The samples were immediately mixed with $2 \mu \mathrm{L}$ of saturated solution of $\alpha$-cyano-hydroxy cinnamic acid (HCCA, Bruker Daltonics) in 50\% acetonitrile (Sigma-Aldrich, Taufkirchen, Germany), supplemented with 2.5\% trifluoroacetic acid (Roth, Karlsruhe, Germany). The matrix/sample spots were crystallized by air drying. Spectra of bacterial strains from the KMM collection of our Institute, as well as reference strains from different commercial collections, were used for comparison. Spectra were calibrated with external calibration by Escherichia coli DH5 alpha standard and protein calibration standard I (Bruker Daltonics).

\subsection{Incubation of Microorganisms for HRESI MS Analysis of Compounds}

The bacterial strains (CB1-14, CB2-11, and CB2-6) were incubated at $200 \mathrm{rpm}$, at $28^{\circ} \mathrm{C}$ for 7 days, in the $100 \mathrm{~mL}$ liquid-modified MN medium. For preparative isolation of target compounds, the strain CB1-14 was incubated at the same conditions using $12 \mathrm{~L}$ of the medium.

\subsection{Isolation and Structure Identification of 6-epi-Monanchorin}

After incubation, the cells and culture broth of Vibrio sp. (strain CB1-14) were separated by centrifugation at $5000 \mathrm{rpm}$ for $30 \mathrm{~min}$. The cells were suspended in water $(50 \mathrm{~mL})$, frozen, and, after de-freezing, subjected to ultrasonic treatment. Then the suspension was extracted with EtOAc, and the organic phase was evaporated to dryness. Further chromatographic purification of the obtained residue with reversed-phase HPLC (YMC-ODS-A, $250 \times 10 \mathrm{~mm})$ using EtOH- $\mathrm{H}_{2} \mathrm{O}(55: 45 \%+0.05 \%$ TFA) gave pure compound 2 .

6-epi-monanchorin (2, $0.2 \mathrm{mg}$ ), HRESI MS $\mathrm{m} / \mathrm{z} 212.1757[\mathrm{M}+\mathrm{H}]^{+}$(calcd for $\mathrm{C}_{11} \mathrm{H}_{22} \mathrm{~N}_{3} \mathrm{O}, 212.1757$ ). ${ }^{1} \mathrm{H}$ NMR $\left(700 \mathrm{MHz}, \mathrm{CDCl}_{3}\right): 8.74(1 \mathrm{H}$, br.s, H-2), $8.64(1 \mathrm{H}$, br.s, H-4), $7.08(2 \mathrm{H}$, br.s, H-10), $4.84(1 \mathrm{H}, \mathrm{t}$, $J=3.0 \mathrm{~Hz}, \mathrm{H}-1), 3.90(1 \mathrm{H}, \mathrm{ddd}, J=6.0,1.6,7.6 \mathrm{~Hz}, \mathrm{H}-6), 3.33(1 \mathrm{H}, \mathrm{dt}, J=6.0,1.6 \mathrm{~Hz}, \mathrm{H}-5), 2.36(1 \mathrm{H}, \mathrm{m}$, H-9a), 2.24 (2H, m, H-8), 2.13 (1H, m, H-9b), 1.74 (1H, m, H-11a), 1.52 (1H, m, H-11b), $1.40(1 \mathrm{H}, \mathrm{m}$, H- H-12a), $1.30\left(5 \mathrm{H}, \mathrm{m}, \mathrm{H}-12 \mathrm{~b}\right.$ and $\mathrm{H}_{2}-13$ and $\left.\mathrm{H}_{2}-14\right), 0.89\left(3 \mathrm{H}, \mathrm{t}, J=6.7 \mathrm{~Hz}, \mathrm{H}_{3}-15\right)$.

\subsection{DNA Isolation and Amplification and Phylogenetic Analysis of $16 \mathrm{~S}$ rDNA Gene}

Genomic DNAs from bacterial isolates were prepared using NucleoSpin kit (Macherey-Nagel, Germany) according to the recommendation provided by the manufacturer. PCR amplification of $16 \mathrm{~S}$ rDNA gene from all the isolates was performed according to [27], using primers BF-20 (5'-ATCACGCGTAAAAATCT-3') and BR2-22 (5'-CCGCAATATCATTGGTGGT-3'), resulting in about a 1500 bp length PCR product. The purified PCR fragments were sequenced using the ABI PRISM 3130xl Genetic Analyzer (Applied Biosystems) and by the BigDye v.3.1 sequencing kit (Applied Biosystems) (see Table S1 in Supplementary Materials). Obtained sequences were analyzed on the highest percentage of similarities using the Ez-taxon database [8] and the MEGA program version 7 [28]. The $16 \mathrm{~S}$ rRNA phylogenetic tree was constructed using the maximum likelihood (ML) method based on the Tamura 3-parameter model [29], with 1000 bootstrap replications in the MEGA program.

\subsection{Genome Sequencing and Multilocus Sequence Analysis of CB1-14}

A draft genome sequence of the isolate CB1-14 was obtained using 454 GS Junior (Roche Life Science, USA). A de novo assembly was performed using Newbler version 3.0 software Junior (Roche Life Science, USA). The genome sequence was assembled into 621 contigs with 14,322 bp of N50. The estimated genome size was $5.3 \mathrm{Mb}$. Gene prediction and automated genome annotation were 
carried out using RAST v. 2.0 with default parameters [30]. Sequences of eight protein-coding genes (ftsZ, gap $A, g y r B, m r e B, p y r H, r e c A, r p o A$, and top $A$ ) from twenty taxa were retrieved from the CB1-14 draft genome, and from the GenBank/DDBJ/EMBL databases. The MEGA program was used to concatenate, align, and reconstruct the ML, maximum parsimony (MP), and neighbor-joining (NJ) phylogenies with 1000 bootstrap replications. The best-fit model for protein evolution determined in the MEGA program was HKY+G [31]. Split decomposition analysis was performed using SplitsTree version 4.14 .3 with a neighbor net drawing and a Jukes-Cantor correction [32,33].

\section{Conclusions}

Our results present the first evidence of the microbial origin of 6-epi-monanchorin (2), previously isolated from the secreted mucus trapping net of the marine polychaete $C$. variopedatus. Using the $16 \mathrm{~S}$ rRNA gene analysis, it was revealed that diverse Vibrio species are dominant bacteria cultured from the $C$. variopedatus mucus net. In addition, it was shown that these bacteria belong to several different species of the genus Vibrio. The strain CB1-14, producing alkaloid 2, was recognized as a new species in the genus Vibrio by phylogenetic reconstruction using eight protein-coding genes. Our results suggest that filter-feeding polychaetes should be considered as a novel source of alkaloid-producing bacteria.

Supplementary Materials: The following are available online at http://www.mdpi.com/1660-3397/17/4/213/s1. HRESIMS spectra of 6-epi-monanchorin (2) isolated from polychaete Chaetopterus variopedatus and marine bacterium Vibrio sp. CB1-14; ${ }^{1} \mathrm{H}$ NMR spectra for 6-epi-monanchorin (2) isolated from polychaete Chaetopterus variopedatus and marine bacterium Vibrio sp. CB1-14; HPLC chromatograms of culture medium extract and cells extracts of CB1-14 and Table S1. Accession numbers and Chimera identification of 16S rRNA of bacterial isolates. The GenBank accession numbers for all 16S rRNA nucleotide sequences will be available on online on the NCBI server after 20 July 2019.

Author Contributions: T.M., V.S., M.I., L.S., and V.K. wrote the paper; L.S. isolated and purified 6-epi-monanchorin; E.B. performed 16S rDNA study; N.C. and M.I. performed genome sequencing of CB1-14 and MLSA study; R.P. and P.D. performed MS study.

Funding: This work was supported by the Grant No. 17-14-01065 from the RSF (Russian Science Foundation).

Acknowledgments: The authors are grateful to Guzev K.V. for nucleotide sequencing of 16S rDNA sequences and Dr. Grebnev B.B. for the animal identification. The spectral data were obtained on the equipment of the Collective Facilities Center (The Far Eastern Center for Structural Molecular Research (NMR/MS) PIBOC FEB RAS).

Conflicts of Interest: The authors declare no conflict of interest. The founding sponsors had no role in the design of the study; in the collection, analyses, or interpretation of data; in the writing of the manuscript, and in the decision to publish the results.

\section{References}

1. Berlinck, R.G.S.; Bertonha, A.F.; Takaki, M.; Rodriguez, J.P.G. The chemistry and biology of guanidine natural products. Nat. Prod. Rep. 2017, 34, 1264-1301. [CrossRef]

2. Meragelman, K.M.; McKee, T.C.; McMahon, J.B. Monanchorin, a bicyclic alkaloid from the sponge Monanchora ungiculata. J. Nat. Prod. 2004, 67, 1165-1167. [CrossRef]

3. Abdjul, D.B.; Yamazaki, H.; Kanno, S.; Takahashi, O.; Kirikoshi, R.; Ukai, K.; Namikoshi, M. Haliclonadiamine derivatives and 6-epi-monanchorin from the marine sponge Halichondria panicea collected at Iriomote Island. J. Nat. Prod. 2016, 79, 1149-1154. [CrossRef] [PubMed]

4. Shubina, L.K.; Makarieva, T.N.; Denisenko, V.A.; Dmitrenok, P.S.; Dyshlovoy, S.A.; von Amsberg, G.; Glazunov, V.P.; Silchenko, A.S.; Stonik, I.V.; Lee, H.S.; et al. Absolute configuration and body part distribution of alkaloid 6-epi-monanchorin from the marine polychaete Chaetopterus variopedatus. Nat. Prod. Commun. 2016, 11, 1253-1257. [CrossRef] [PubMed]

5. Enders, H.E. A study of the life history and habits of Chaetopterus variopedatus. J. Morphol. 1909, 20, 479-531. [CrossRef]

6. MacGinitie, G.E. The method of feeding in Chaetopterus. Biol. Bull. 1939, 77, 115-118. [CrossRef]

7. Waterbury, J.B.; Stanier, R.Y. Isolation and Growth of Cyanobacteria from Marine and Hypersaline Environments. In The Prokaryotes; Starr, M.P., Stolp, H., Trüper, H.G., Balows, A., Schlegel, H.G., Eds.; Springer: Berlin, Germany, 1981; pp. 221-223. 
8. Kim, O.S.; Cho, Y.J.; Lee, K.; Yoon, S.H.; Kim, M.; Na, H.; Park, S.C.; Jeon, Y.S.; Lee, J.H.; Yi, H.; et al. Introducing EzTaxon-e: A prokaryotic 16S rRNA gene sequence database with phylotypes that represent uncultured species. Int. J. Syst. Evol. Microbiol. 2012, 62, 716-721. [CrossRef]

9. Kim, M.; Oh, H.S.; Park, S.C.; Chun, J. Towards a taxonomic coherence between average nucleotide identity and 16S rRNA gene sequence similarity for species demarcation of prokaryotes. Int. J. Syst. Evol. Microbiol. 2014, 64, 346-351. [CrossRef]

10. Kita-Tsukamoto, K.; Oyaizu, H.; Nanba, K.; Simidu, U. Phylogenetic relationships of marine bacteria, mainly members of the family Vibrionaceae, determined on the basis of $16 \mathrm{~S}$ rRNA sequences. Int. J. Syst. Bacteriol. 1993, 43, 8-19. [CrossRef] [PubMed]

11. Sawabe, T.; Kita-Tsukamoto, K.; Thompson, F.L. Inferring the evolutionary history of Vibrios by means of multilocus sequence analysis. J. Bacteriol. 2007, 189, 7932-7936. [CrossRef] [PubMed]

12. Sawabe, T.; Ogura, Y.; Matsumura, Y.; Gao, F.; Amin, A.K.M.; Mino, S.; Nakagawa, S.; Sawabe, T.; Kumar, R.; Fukui, Y.; Satomi, M. Updating the Vibrio clades defined by multilocus sequence phylogeny: Proposal of eight new clades, and the description of Vibrio tritonius sp. nov. Front. Microbiol. 2013, 4, 414. [CrossRef]

13. Rizzo, C.; Lo Giudice, A. Marine Invertebrates: Underexplored Sources of Bacteria Producing Biologically Active Molecules. Diversity (Basel) 2018, 10, 52. [CrossRef]

14. Schmitz, F.J.; Vanderah, D.J.; Hollenbeak, K.H.; Enwall, C.E.L.; Gopichand, Y.; Sengupta, P.K.; Hossain, M.B.; van der Helm, D. Metabolites from the marine sponge Tedania ignes-A new atisanediol and several known diketopiperazines. J. Org. Chem. 1983, 48, 3941-3945. [CrossRef]

15. Nicacio, K.J.; Ioca, L.P.; Froes, A.M.; Leomil, L.; Appolinario, L.R.; Thompson, C.C.; Thompson, F.L.; Ferreira, A.G.; Williams, D.E.; Andersen, R.J.; et al. Cultures of the Marine Bacterium Pseudovibrio denitrificans Ab134 Produce Bromotyrosine-Derived Alkaloids Previously Only Isolated from Marine Sponges. J. Nat. Prod. 2018, 80, 235-240. [CrossRef]

16. Stierle, A.C.; Cardellina, J.H., II; Singleton, F.L. A marine micrococus produces metabolites ascribed to the sponge Tedania ignis. Experientia 1988, 44, 1021. [CrossRef]

17. Elyakov, G.B.; Kuznetsova, T.A.; Mikhailov, V.V.; Maltsev, I.I.; Voinov, V.G.; Fedoreyev, S.A. Brominated diphenyl ethers from a marine bacterium associated with the sponge Dysidea sp. Experientia 1991, 47, 632-633. [CrossRef]

18. Agarwal, V.; El Gamal, A.A.; Yamanaka, K.; Poth, D.; Kersten, R.D.; Schorn, M.; Allen, E.E.; Moore, B.S. Biosynthesis of polybrominated aromatic organic compounds by marine bacteria. Nat. Chem. Biol. 2014, 10, 640-647. [CrossRef]

19. Unson, M.D.; Faulkner, D.J. Cyanobacterial symbiont biosynthesis of chlorinated metabolites from Dysidea herbacea (Porifera). Experientia 1993, 49, 349-353. [CrossRef]

20. Oclarit, J.M.; Okada, H.; Ohta, S.; Kaminura, K.; Yamaoka, Y.; Iizuka, T.; Miyashiro, S.; Ikegami, S. Anti-bacillus substance in the marine sponge Hyatella species, prodiced by an associated Vibrio species bacterium. Microbios 1994, 78, 7-16.

21. Schmidt, E.W.; Donia, M.S.; McIntosh, J.A.; Fricke, W.F.; Ravel, J. Origin and Variation of Tunicate Secondary Metabolites. J. Nat. Prod. 2012, 75, 95-304. [CrossRef]

22. Rizzo, C.; Michaud, L.; Hormann, B.; Gerce, B.; Syldatk, C.; Hausmann, R.; De Domenico, E.; Lo Giudice, A. Bacteria associated with sabellids (Polychaeta: Annelida) as a novel source of surface active compounds. Mar. Pollut. Bull. 2013, 70, 125-133. [CrossRef]

23. Lemos, M.L.; Balado, M.; Osorio, C.R. Anguibactin- versus vanchrobactin-mediated iron uptake in Vibrio anguillarum: Evolution and ecology of a fish pathogen. Environ. Microbiol. Rep. 2010, 2, 19-26. [CrossRef]

24. Noguchi, T.; Hwang, D.F.; Arakawa, O.; Sugita, H.; Deguchi, Y.; Shida, Y.; Hashimoto, K. Vibrio alginolyticus, a tetrodotoxin-producing bacterium, in the intestines of the fish Fugu-Vermicularis vermicularis. Mar. Biol. 1987, 94, 625-630. [CrossRef]

25. Lee, M.J.; Jeong, D.Y.; Kim, W.S.; Kim, H.D.; Kim, C.H.; Park, W.W.; Park, Y.H.; Kim, K.S.; Kim, H.M.; Kim, D.S. A tetrodotoxin-producing Vibrio strain, LM-1, from the puffer fish Fugu Vermicularis radiatus. Appl. Environ. Microbiol. 2000, 66, 1698-1701. [CrossRef]

26. Noguchi, T.; Ali, A.E.; Arakawa, O.; Miyazawa, K.; Kanoh, S.; Shida, Y.; Nishio, S.; Hashimoto, K. Tetrodonic acid-like substance-A possible precursor of tetrodotoxin. Toxicon 1991, 29, 845-855. [CrossRef] 
27. Noguchi, T.; Jeon, J.K.; Arakawa, O.; Sugita, H.; Deguchi, Y.; Shida, Y.; Hashimoto, K. Occurrence of tetrodotoxin and anhydrotetrodotoxin in Vibrio sp. isolated from the intestines of a xanthid crab, Atergatis floridus. J. Biochem. 1986, 99, 311-314. [CrossRef]

28. Stenkova, A.M.; Isaeva, M.P.; Shubin, F.N.; Rasskazov, V.A.; Rakin, A.V. Trends of the Major Porin Gene (ompF) Evolution: Insight from the Genus Yersinia. PLoS ONE 2011, 6, e20546. [CrossRef]

29. Kumar, S.; Stecher, G.; Tamura, K. MEGA7: Molecular evolutionary genetics analysis version 7.0 for bigger datasets. Mol. Biol. Evol. 2016, 33, 1870-1874. [CrossRef]

30. Tamura, K. Estimation of the number of nucleotide substitutions when there are strong transition-transversion and G+C-content biases. Mol. Biol. Evol. 1992, 9, 678-687. [CrossRef]

31. Aziz, R.K.; Bartels, D.; Best, A.A.; DeJongh, M.; Disz, T.; Edwards, R.A.; Zagnitko, O. The RAST Server: Rapid annotations using subsystems technology. BMC Genomics 2008, 9, 75. [CrossRef]

32. Hasegawa, M.; Kishino, H.; Yano, T. Dating of the human-ape splitting by a molecular clock of mitochondrial DNA. J. Mol. Evol. 1985, 22, 160-174. [CrossRef]

33. Bandelt, H.J.; Dress, A.W.M. Split decomposition: A new and useful approach to phylogenetic analysis of distance data. Mol. Phylogenet. Evol. 1992, 1, 242-252. [CrossRef]

(C) 2019 by the authors. Licensee MDPI, Basel, Switzerland. This article is an open access article distributed under the terms and conditions of the Creative Commons Attribution (CC BY) license (http://creativecommons.org/licenses/by/4.0/). 